\title{
FOOD AND AGRICULTURE IN THE NEW COLONY OF VAN DIEMEN'S LAND, 1803 TO 1810
}

\author{
by Trevor D. Semmens
}

(with four tables and one text-figures)

SEMMENS, T.D., 1988 (31:x): Food and agriculture in the new colony of Van Diemen's Land, 1803 to 1810. Pap. Proc. R. Soc. Tasm., 122(2): 19-29. https://doi.org/10.26749/rstpp.122.2.19 ISSN 0080-4703. Entomology Section, Department of Agriculture, G.P.O. Box 192B, Hobart, Tasmania, Australia 7001.

The new settlement of Van Diemen's Land and its first eight years are looked at in the light of the feeding of this young colony, and the development of agriculture to allow for sufficiency in food. For many reasons development was slow and progress limited.

Key Words: food, agriculture, Van Diemen's Land, famine.

".... For Wise and Good reasons to promote the Interest of the British Nation and Secure the Advantages that may be derived from the Fisheries, etc., etc., in the Colony ... to form a Settlement On the South Part of this Coast, or Isles Adjacent, to Counteract any Projects or plans the French Republic may arrainge... [I] intrust you with the Charge of forming Such Establishment"...

Part of Order given to Lieut Bowen, 29 March 1803 (H.R.A. III(1): 190-191)

\section{IN THE BEGINNING ... THE DEPENDENT COLONY}

\section{At Settlement - Risdon Cove}

After several abortive attempts, settlement of Risdon Cove by Lieut John Bowen and his small party occurred on 8 September 1803. This settlement started the new colony.

In instructions given to Bowen on 28 March 1803 (H.R.A. I(4): 152), the following had specific regard to food and agriculture:

"After taking measures to secure yourself and people and stores you will proceed to clear ground on the public account for the cultivation of wheat and other plants."

"You are to inform yourself of the nature of the soil, what proportions of land you find proper for the cultivation of wheat, barley and flax ... what quantity of cattle can be taken care of ..."

"You are to fix the settlers ... [the] ground you may intend to allot for cultivation on the public account; and as they are free settlers you will, as they are the first, allot 200 acres ( 81 ha) to each family and victual them for eighteen months. They are to be allowed the labour of two convicts each during that time, and to be supplied with such portions of seed, grain, garden seeds and stock as can be spared; and also tools."

Instructions were reissued on 10 June 1803 and were much less liberal (H.R.A. III(1): 193) viz.:

"To have town lots of 5 acres ( 2 ha) each, on lease 14 years, and when circumstances will allow to have a grant of 100 acres (40.47 ha) each, subject to the usual quit rents. To be victualled 12 months from the time of taking possession of their town lots. To be allowed the labour of 2 convicts victualled for the same term; after which they and their families are to be of no further expense to Government."

"To have 2 ewes each, 6 bushels $\left(0.22 \mathrm{~m}^{3}\right)$ of seed wheat, a proportion of tools, nails, clothing and such garden seeds as can be spared ..." "Should any unforeseen circumstances ... induce the Commandant to continue them longer on the stores from loss of crops, etc., he is at liberty to do it ..."

Additional instructions furnished in a "memorandum for Mr. Bowen" included the following:

"Be careful the people get their ration given clear $-4 \mathrm{lbs}(1.82 \mathrm{~kg})$ pork and $7 \mathrm{lbs}(3.18 \mathrm{~kg})$ biscuit a week."

"Slops are to be issued in December and June ..." [This refers to ready made or cheap clothing, not food "slops"!] 
"Everyman except ... to be kept employed at the public labour in securing the provisions and stores ..."

As at 27 September 1803 the Risdon Cove community consisted of "49 souls". A return of lives tock landed showed: Government stock - 1 bull, 8 cows, 2 rams, 16 ewes, 4 ewe lambs, 3 wether lambs. Private stock -1 mare, 8 goats, 38 pigs, 7 sheep, 1 cow.

In a short time the two free settlers had their blocks ready for sowing and the Surgeon, Mountgarrett, had a few acres ready. But there was no ground prepared for cultivation on Government account. The latter was due to the fractious nature and the lack of ability of the convicts. (The Administrator would have profited from reading Francis Bacon's "Essay on Plantations" where he said, "It is a shameful and un-blessed thing to take the scum of people and wicked condemned men to be the people with whom you plant a colony" (Barrett 1936).)

\section{Settlement at Sullivan Cove}

On 16 February 1804, Lieut Governor Collins arrived at Risdon Cove and was most disappointed at its positioning for a permanent settlement. Next day he and others "went to examine a plain on the S.W. side of the river" (Nicholls 1977). They were delighted with this site which was called Sullivan Cove. So Collins settled there. It had a good water supply and the loading and unloading of ships was not difficult, and the soil at least equal to that at Risdon Cove.

Governor Collins viewed his expedition as an attempt to establish a new colony. It consisted of free settlers who were to till the land and raise crops and cattle so as to make the colony independent in the matter of food supplies. It was not to be thus independent in his period of office.

The first General Orders were issued by Collins on 28 February 1804 (HRA III(1): 219) and included the following as regard provisions:

"The storekeeper will issue the following weekly ration until further orders, viz:-

To civil, military, free settlers and prisoners -

$7 \mathrm{lb} .(3.18 \mathrm{~kg})$ Beef or $4 \mathrm{lb} .(1.82 \mathrm{~kg})$ Pork

$7 \mathrm{lb}$. Flour

6 oz. $(0.17 \mathrm{~kg})$ Sugar

To women two-thirds, children above five years half and children under five years one fourth of the above rations.

The issuing days for provisions will be in future Tuesdays and Saturdays.
The military will receive half a pint $(0.281)$ o spirits daily as before."

They were urged "under pain of being severely punished", to keep the supply of pure running water from being polluted. To store all the provisions brought in, a temporary wooden storehouse was erected on Hunter's Island.

A site three miles $(4.8 \mathrm{~km})$ away was picked for the Government Farm and was named Farm Bay (now Cornelian Bay) and the settlers were located in the next bay, Stainforth's Cove (now New Town Bay).

The settlers were entitled to land grants of 100 acres (40.47 ha) each, which were to be made by the Governor of New South Wales (N.S.W.) on the recommendation of Lieut Governor Collins. In addition, they and their families were to be victualled from the public stores for twelve months, and assisted with tools, seed grain and the services of whatever spare convicts could be assigned to them. Collins was anxious they should prove "by their exertions, abilities and propriety of conduct that they are deserving of being trusted with stock and are likely to support themselves independent of the public stores", before being eligible for the land grant. In spite of lack of convict labour, the settlers in the first season harvested a crop which gave them a small surplus over the requirement for seed. Meanwhile, on the Government Farm a lot of work had been done. In July 1804 there were 19.5 acres (7.9 ha) of wheat, 1.75 acres $(0.29 \mathrm{ha})$ of oats and 2.25 acres $(0.91 \mathrm{ha})$ of rye. Interestingly, all the seed grain brought out from England was spoilt (or was poor to start with) and did not germinate. (Note: At Port Phillip, the aborted settlement prior to Sullivan Cove, "...18 or 20 different sorts of [garden] seeds which were put into the ground, not one succeeded" (HRA III(1): 221).) Fortunately, further supplies which had been purchased at Cape Town and some from Sydney proved satisfactory.

Because of the scarcity of labour and the urgency of getting agricultural work underway, Collins allowed the convicts to work with the settlers in their spare time. Without the convicts' aid the settlers would have made little progress. Even at this very early stage, "labour troubles" beset the small community, forcing Collins on 22 June 1804 to issue a General Order fixing the price of labour (HRA III(1): 270). Some agricultural wage rates were:

"For felling and burning of timber,

per acre

Grubbing and burning, per acre $4 / 0 / 0$

Breaking up new ground $3 \mathrm{~d}$. per rood, per acre 
Chipping ground $2 \mathrm{~d}$. per rood, per acre

in seed $l$ and a half pence per rood,

per acre

Breaking up stubble ground $2 \mathrm{~d}$. per rood, per acre

Digging garden ground, per rood

Reaping an acre of wheat

Threshing wheat per bushel

Meanwhile the two settlers at Risdon Cove, Birt and Clark elected to stay on there till their crop was harvested, after which both moved out to Sydney and Sullivan Cove respectively.

The next shipment of livestock arrived from Sydney on 25 June 1804 after an extremely tempestuous passage of 32 days. Many of the stock died.

A return of livestock in the colony, dated 4 August 1804 showed:

$\begin{array}{lrlrlr}\text { horses } & \text { nil } & \text { bulls } & 3 & \text { cows } & 10 \\ \text { calves } & 8 & & & & \\ \text { rams } & 4 & \text { ewes } & 34 & \text { wethers } & 2 \\ \text { lambs } & 21 & & & & \\ \text { he-goats } & 1 & \text { she-goats } 10 & \text { kids } & 7 \\ \text { boars } & 6 & \text { sows } & 21 & \text { pigs } & 29 \\ \text { geese } & 12 & \text { ducks } & 31 & \text { turkeys } & 12 \\ \text { fowls } & 123 & & & & \end{array}$

Of the above, all the cattle and sheep belonged to the Government, with the remainder chiefly in the hands of the officers. Generally each settler possessed only a few head of poultry.

The shortage of livestock was relieved by the arrival, on 8 August 1804, of a shipment from India. In consisted of 130 cows, 60 oxen, 1 bull, 1 stallion, 3 mares, 59 sows and 2 boars. The cows were the small Bengal breed - but when crossed with English bulls produced animals of better breed and larger size. These were all for the Government and were sent to the Government Farm. The settlers had to purchase stock how and when they could chiefly from vessels which happened to visit the port for the purposes of trading. Within the next twelve months, Lieut Governor Collins realised the necessity of assisting settlers with stock, which were then sold to them on the express condition that they not be alienated till the second generation.

At this time there was a severe shortage of specie (coinage) in the colony, and as a result workers bartered their labour for a surprising variety of items. These included soap, wine, meat, flour, clothing, shoes, cows, pins, buttons and rum, which was one of the favoured items (Barrett 1936). As a result, it was found necessary to fix the price at which articles could be paid for labour. The following were specified: salted beef, $9 \mathrm{~d}$. per pound; salted pork, 1/- per pound; kangaroo, 8d. per pound; flour, l/- per pound; and wheatmeal, 6d. per pound (see table 1).

Methods of agriculture were necessarily very primitive. The settlers had no horses of their own and no ploughing was done. The ground was roughly cleared and then broken up with a hoe and the seed roughly sown, or, as often as not, simply chipped in. It was hard work indeed.

Over a period of time (see section "Land Grants and Agriculture"), some of the settlers and civil and military officers were granted land. These grants date from 15 August 1804. Because of trouble experienced in N.S.W. by the N.S.W. Corps, officers were allowed to engage in agriculture, but were strictly forbidden to trade.

\section{Settlement at Port Dalrymple}

In November 1804, the first settlement was temporarily set up at Outer Cove (now George Town), but because of gales and uncertainty regarding the dangerous entry into the Tamar River, an amount of stores, spirits and salted provisions were landed on Green Island. Shortly afterwards a further settlement was made at Yorkton but this was also found not particularly suitable for a permanent settlement. Thus the site now known as Launceston was settled.

The first shipment of livestock to this new settlement arrived in March 1805. However, the stock suffered badly on the stormy passage and there were landed only one mule, two oxen, two calves, three sheep, two boars and thirteen sows. Shortly afterwards a large consignment from India was diverted to Port Dalrymple. Landed were 612 cows, 10 calves and 34 ewes together with a quantity of rice and salted meat. The cost of this shipment was immense - $£ 15350$. $£ 25$ was paid for each cow landed and $£ 5$ for each calf. Nine hundred and ten animals were put on board, but 298 died during the voyage. The winter cold took a heavy toll on what cattle were left and only 250 remained at the end of 1805 . Within a few days another shipment arrived. It consisted of 120 ewes, 2 rams, 6 cows, 2 bulls, 1 mare and 1 horse. In this regard Governor King assisted Lieut Governor Paterson and his small settlement at Port Dalrymple more than Collins at Sullivans Cove.

In spite of this help, the settlement did not prosper and in 1806 there were only three settlers established (in 1808 still only three and by 1810 only sixteen). However, $\mathrm{Mr}$ Mountgarrett, the Surgeon (formerly of Risdon settlement), and 


\title{
TABLE 1 \\ Food Costs
}

\begin{abstract}
During the early years in the colony food was very expensive as shown by prices relative to
\end{abstract} 1985 wage ates. Note: a wage of $£ 50$ per annum was good for workers in that early 1800 's period.

Item

Meat - Salted beef
$\quad$ - salted pork
Bread - kangaroo
$\quad 1$ st quality
Tea inferior
Biscuit
Maize
Sugar
Rice
Potatoes
Corn
Soap
Tobacco
Wheat
Barley
Pumpkin
Spirits

Actual cost

$9 \mathrm{~d}$ per lb

$1 /$ - to $3 /$ - per lb

8 d to $1 /-$ per lb

$8 \mathrm{~d}$ to 2.6 per $\mathrm{lb}$

$41 / 2 \mathrm{~d}$ per lb

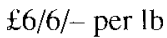

$4 /-$ per lb

$3 / 6$ per $\mathrm{lb}$

$10 \mathrm{~d}$ to $£ 1$ per Ib

$2 / 6$ per lb

$1 / 6$ to $2 /-$ per lb

$7 /-$ per $\mathrm{lb}$

$121 / 2 \mathrm{~d}$ per $\mathrm{lb}$

$£ 1$ to $£ 2 / 10 /-$ per lb

$25 /$ - to $£ 6+$ per bushel

$£ 5$ per bushel

9/- each

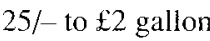

\section{Price relative al 1985 wage rates}

$\$ 34.34$ per $\mathrm{kg}$
$\$ 42.92$ to $\$ 128.76$ per $\mathrm{kg}$
$\$ 30.04$ to $\$ 42.92$ per $\mathrm{kg}$
$\$ 30.04$ to $\$ 107.30$ per $\mathrm{kg}$
$\$ 16.10$ per $\mathrm{kg}$
$\$ 5407.92$ per $\mathrm{kg}$
$\$ 171.68$ per $\mathrm{kg}$
$\$ 150.22$ per $\mathrm{kg}$
$\$ 35.77$ to $\$ 858.40$ per $\mathrm{kg}$
$\$ 107.30$ per $\mathrm{kg}$
$\$ 64.38$ to $\$ 85.84$ per $\mathrm{kg}$
$\$ 300.44$ per $\mathrm{kg}$
$\$ 43.64$ per $\mathrm{kg}$
$\$ 858.40$ to $\$ 2146$ per $\mathrm{kg}$
$\$ 13413$ to $\$ 64369$ per $\mathrm{m}^{3}$
$\$ 53658$ per $\mathrm{m}^{3}$
$\$ 175.59$ each
$\$ 107.20$ to $\$ 171.52$ per litre

Mr Riley, the Storekeeper, had been most energetic and in 1806 had sown 53 acres ( 24 ha) of wheat, 23 acres ( $10.4 \mathrm{ha}$ ) of barley and 4 acres (1.8 ha) of potatoes. No cultivation had been undertaken on Government account though it possessed virtually all the livestock. Of the population of 276 (August 1806), all except three adults and two children were victualled from the Government store.

\section{THE FAMINE - APRIL 1805 TO DECEMBER 1807}

For nearly three years - from April 1805 to December 1807 - the Derwent settlement and, for nearly that period, Port Dalrymple were very short of provisions. For most of the time both settlements were on a very much reduced ration and at some periods they were on the verge of famine. Supplies of meat were considerably augmented by the issue of kangaroo and emu: indeed the kangaroo was the salvation of the settlements. Small shipments of provisions were received at intervals from Port Jackson, and some rice from India, and these helped to eke out supplies, but it was not until the early part of 1808 that the settlements were placed beyond the reach of want, and the harvest of 1808 at the Derwent settlement in fact provided a small surplus for export to Port Jackson.

During these three years the colony made no progress whatever. Work was practically at a standstill, for little labour could be expected from prisoners on a ration that was hardly sufficient to keep body and soul together. Cultivation was neglected because a large proportion of the assigned servants were hunting kangaroos, and there was not sufficient labour to till the fields. Besides, the masters found it more profitable to sell kangaroo to the Government at 1 -- per pound than to take the risk of growing wheat to sell at $10 /-$ per bushel. 
The general orders issued from June 1805 to 1808 give a very vivid picture of the state of the crwent settlement. The orders are very numerous, we nearly all concerned with the subject of rations, ane are most melancholy reading. Port Dalrymple wa in exaclly the same straits, but this survey is iefly contined to the Derwent, because we have ure information about that part of the island.

On 4 March 1805, the returns of the Deputy ommissary showed that there was only 21 weeks supply of salt meat in store, and as no shipment arrived during the next few weeks the issue of beef was reduced by half. To save the flour, the issue was reduced to $6 \mathrm{lbs}(2.72 \mathrm{~kg})$, and to make up the ration, $6 \mathrm{lbs}(2.72 \mathrm{~kg})$ of wheat were issued. On 14 June, even at the reduced ration, there was only 12 wecks supply of pork in the store, 22 weeks of flour and 7 weeks of wheat. Within a few days the Richard and Mary brought two weeks supply of flour and five weeks of beef and pork, and the next month the Sophia brought three weeks supply of pork. Unfortunately, nearly half of the Sophia's consignment had to be jettisoned in a gale to lighten the ship. In order to save the salted meat as much as possible, on 2 August the Lieut Governor notified that kangaroo would be received into store at $1 /$ - per pound and issed at the rate of $2 \mathrm{lbs}$ $(0.91 \mathrm{~kg})$ for one of salted meat. The balance of the ration was made up of $2 \mathrm{lbs}$ flour, $2 \mathrm{lbs}$ wheatmeal, $2 \mathrm{lbs}$ wheat and $12 \mathrm{oz} .(0.34 \mathrm{~kg})$ sugar. By the end of the month the flour was cut out of the ration, the wheatmeal was expended, and the deficiency was made up by an extra $1 \mathrm{Ib}$ each of wheat and rice, and an inerease to $1 \mathrm{lb}$ of sugar of which there was a good supply.

Early in August 1805, Rev. Knopwood also records a shortage in another article necessary as a beverage and a means of barter (Nicholls 1977) "not a drop of spirits in the Colony". On 7 September the wheat was expended also, and flour had to be issued instead. On 14 September the first "soup kitchen" was opened in Hobart Town. The general order read,

"The Lt. Governor having directed that a quantity of Kangaroo should be boiled into soup at the General Hospital one quart thereof will be issued daily at the hour of 12 to such persons as choose to apply for same, and until further orders."

This soup was made from the fore-quarters, on which there was little meat, and which were unsuitable for issue as rations.

Small shipments by the Richard and Mary, and the Governor Hunter in October, and a large consignment by the Sydney in November enabled the Lieut Governor to increase the weekly issue to nearly the full ration. Hours of labour had been relaxed during the shortage, but the Governor found no increase in the work being done on the improved ration. Some maize arrived by the Sophic in January 1806. The harvest of 1805 was only about 300 bushels $\left(10.92 \mathrm{~m}^{3}\right)$ and that of 1806 was not likely to be much more. Collins offered $10 \%$ per bushel for it, and saying that "better grain could no-where be produced" recommended "all persons holding land to make every possible progress in the cultivation thereof".

By April 1806 provisions were getting very low and the rations had to be reduced again. And two unfortunate eircumstances were to add 10 the distress of the colony. Large quantities of salted pork received by various vessels were found to be quite unfit for human consumption. Collins wrote on 20 April 1806 (HRA III(1): 357),

"I have been for a considerable time past issuing salted pork that under no other cireumstances than those in which I unfortunately found myself would have been received into His Majesty's Stores, or considered as possible to be eaten."

The Sophia's consignment from Norfolk Island was so bad that $16000 \mathrm{lbs}(7264 \mathrm{~kg}$ ) (three months supply) was condemned, being "rancid, rotten and unfit to eat". This was occasioned by lack of salt and leaky casks, but in many cases the Government stores had been imposed upon, as casks were found to contain merely heads and feet, or else good pieces at either end, and in the middile meat that ought to have been destroyed.

In March 1806 the great granary of the colonies - the Hawkesbury River district experienced disastrous floods. Stacks of grain which had been harvested from 4500 acres (1821 ha) of wheat and barley were swept away and 2424 acres (981 ha) under maize were ruined, so that the Mother Colony herself was faced with a very serious prospect. Governor King at once sent off to India for a cargo of rice, but it was several months before it arrived. King therefore did his best to send to the Derwent and Port Dalrymple settlements whatever immediate help was possible from his scanty resources by means of his small vessels. On 16 June the brig Venus, one of the two vessels which King had hurried off, was piratically seized at Port Dalrymple by the mate and crew before she had unloaded any of her cargo of much-needed provisions.

The first execution in Tasmania was occasioned by a robbery of the Government stores 
at Port Dalrymple. On 18 January 1806, three soldiers and James Keating, cooper at the stores, broke open three casks and stole $35 \mathrm{lbs}(15.9 \mathrm{~kg})$ of pork. All were sentenced to death, and Keating was sent to Hobart Town and was executed publicly on 14 April. Theft was a serious (though common) crime in any circumstances, but robbery of the stores when the colony was in such sore straits, and by those whose duty it was to guard them, was indeed a crime of great magnitude.

Prices of provisions inevitably soared. Thus, by a general order of 9 June, the number of public bakers was limited to four. They were to have the sole right to bake bread for the inhabitants for a period of six months. A standard loaf was to be produced at a fixed price. No bread was to be made "during the present scarcity" of a "finer quality than a sample household bread which was produced by Richard Coleman and approved by the Magistrates, and for which the bakers are allowed to charge $8 \mathrm{~d}$. per $\mathrm{lb}$., and 4 and a half pence for bread of an inferior quality" (HRA III(1): 542). The price of wheat was fixed at not more than $25 /-$ per bushel $\left(3.64 \times 10^{-2} \mathrm{~m}^{3}\right)$. The penalty on conviction for "offering or giving more than the above mentioned prices" was $£ 10$.

By the end of July the provisions had been considerably reduced, and the ration consisted of 8 lbs $(3.6 \mathrm{~kg})$ of kangaroo meat and only $3 \mathrm{lbs}$ $(1.37 \mathrm{~kg})$ of flour of wheat for the civil, military and free persons, and $2 \mathrm{lbs}(0.91 \mathrm{~kg})$ of wheat to the male prisoners.

A small supply was received early in August via the Governor Hunter from Port Jackson, and a liberal ration of salted pork and beef was issued, with a few pounds of meal and maize. There was no grain in the settlement, so Collins thought it his duty to write to the Commandant at the Cape of Good Hope urging him to send whatever supplies he could. Tea was also a very scarce commodity. Knopwood's notes of 25 August 1806 stated (Nicholls 1977), "Captain Sladen's sale was this morn, and one pound of tea was sold at the enormous price of six guineas a pound and bought by Lt. Lord."

The scarcity of provisions led to frequent robberies and depradations, including the slaughter of both public and private stock. Rev. Knopwood on 27 September 1806, had this to say about the situation:

"The prisoners very greatly distressed for provisions, not any flour, meal or maize in store. This day things sold at the following price:Biscuit $4 /-$ per lb. meal $3 / 6$ do. maize $3 / 3$ do. tobacco not fit to be made use of $2 / 6$ per inch.
The Colony very greatly distressed 10 everything and everybody crying out for the wist of bread, sugar 5/- per lb., rice $2 / 6$ per lb. anc kangaroo at 1/- per lb." (Nicholls 1977).

The Deputy Judge Advocate, Mr Bate, who had recently arrived, sold flour for $6 /-$ per $1 b$. Often men went fishing for it was their only chance of getting something to eat. The whaler King George arrived on 6 October with a small supply of salted meat, but no grain or flour, a supply which relieved the situation a little.

Shortly afterwards (13 October) Knopwood wrote, painting a terrible picture of conditions:

"It is truly lamentable to see the distress that the people are in not a man able to do any work, what few there employed in unloading the "King George" the Lt. Governor is obliged to give them pork and beef 4 lb a man all our poultry are dying having nothing to give them. The poor piggs etc etc are all dying ... My poor pigeons are all most dead for want of provisions only 4 remaining out of 16" (Nicholls 1977).

\section{A fortnight later,}

"The distress of the Colony beyond conception meat $3 / 6 \mathrm{lb}$. coarse meat $9 /-$ and potatoes $1 / 6$ a pound. Indian corn $7 /-\mathrm{a} \mathrm{lb}$. and very bad, and a very little to be obtained. No work to be done, The poor people go out afishing."

Some biscuit came by the Ferret on 1 November and was immediately issued: flour $1 \mathrm{lb}$ and biscuit $2 \mathrm{lb}$ to civil, military and free persons and to male prisoners $2 \mathrm{lb}$ biscuit, with the usual proportions to women and children. The crew of the Ferret very seifishly tried to prevent this small assistance being given, and the Lieut Governor punished six of them with 200 lashes each for refusing to let land two casks of biscuit and three of flour for the relief of the colony. This lasted for barely a month and the inhabitants were again on short rations: kangaroo and emu were once more received into store - this time at the advanced price of $1 / 6$ per $1 b$.

The new season's wheat crop was a small one. The return of 18 October 1806 showed only 49.5 acres ( 20 ha) wheat in on Government account and 52 acres ( 21 ha) between all the settlers. As a result the price was $£ 4$ per bushel.

Certain settlers, in fact, combined to raise the price to $£ 6$. By general order of 7 February 1807, Collins forbade anyone offering or giving a greater price than $£ 4$. This order was quite ineffective. Just a fortnight later Knopwood mentions that 
"wheat was not to be obtained at $£ 6$ per bushell, and barley $\mathfrak{f} 5$. Tobacco is also very scarce indeed - Rio tobacco fetching as much as $£ 2 / 10 /-$ per lb. and sugar very coarse $\notin 1$ per lb. There was not a piece of lump sugar in the Colony" (Nicholls 1977).

The long-expected cargo of rice from India arrived in the Duchess of York on 5 March. She fired a gun at sunrise, and "the whole of the prisoners were so rejoiced that they gave three cheers". The ship brought many other things besides rice. On 7 March, Knopwood records: "a quantity of spirit was landed and almost everybody was drunk" (Nicholls 1977) — the result no doubt of long abstention, and exuberance of joy for the relief of their distress. A further supply of wheat and rice was received from Port Jackson via the Estremina shortly afterwards, and the colony was placed on a better ration for a few months. On 29 April, the Lieut Governor sent for the bakers and reduced the price of bread for a fine $2 \mathrm{lb}$ loaf from $5 /-$ to $4 /-$

Next month the salt meat in store was too bad to issue and kangaroo had to be resorted to again for a few weeks until a further shipment came from Sydney in the Elizabeth. By the beginning of August 1807, the wheat, flour and maize were all spent and there was only rice to issue. The salt meat was also getting scarce, and kangaroo was used to supplement the issue.

Governor Bligh, who had succeeded King as Governor-in-Chief, sent down a supply of meat and maize in the Porpoise in October, and this eased the situation somewhat. At the same time he strongly reprimanded Collins for his extravagance in the issue of rations. He pointed out that Collins had issued far too much kangaroo in lieu of other provisions; had paid too high a price for kangaroo and that, in case of want of flour or grain, vegetables and roots are the proper substitutes as the full ration of meat is considered sufficient for any man. Very fine advice to the Lieut Governor who had seen his settlement in dire straits for nearly three years!

On 26 January 1808, Major Johnston deposed Bligh in N.S.W. and from him the subordinate Derwent settlement received better treatment from Sydney. He sent Collins a supply of provisions and assured him that he would continue shipments till he had 12 months stock on hand. Thus ended the disastrous famine.

The reasons for the famine were chiefly three:

(1) Neglect and/or misunderstanding on behalf of the Home Government.
(2) Shipping difficuties. Small ships, delays through weather conditions and loss of stores (e.g. on one occasion when the settlers were practically out of salted meat, of the 60 tierces (casks) loaded, 28 had to be thrown overboard to lighten the ship). (3) Poor quality of provisions. The provisions Collins brought out from England were generally of excellent quality. This was far from being the case with those received a couple of years later from Port Jackson or from Norfolk Island. Huge quantities of salted meat and flour had to be condemned.

\section{NORFOLK ISLAND SETTLERS}

Arriving at the end of the period of famine were some 554 people from Norfolk Island. Many of these were allocated farms on the banks of the Derwent River in the area now called New Norfolk. The grants of land were not as generous as for the first settlers (half in fact), but in other aspects were more liberal (HRA I(6): 73):

"The settlers and other inhabitants are to be divided into three classes -

1st. Diseharged Seamen. Marines and old servants of Government who have proved themselves to be industrious and deserving of favour. 2nd. Persons formerly convicts but who have conducted themselves with propriety, or who have large families, or from other causes may have claims to particular attention.

3rd. Comprehend the remainder of inhabitants possessing land or buildings but who have no particular pretensions to the favour of Government.

To all persons in each of these three classes grants of lands (free of expense) on their arrival at Port Dalrymple or Hobart Town (according to their option) to be made in the proportion of two acres for every one of cieared ground, and one acre for every one of waste land possessed at Norfolk Island. Convenient buildings are to be erected on each allotment for the residence of the settlers at the public expense, in the manner hereafter explained, of equal value with the houses which they left behind.

The settlers of the first class and their families to be victualled and clothed for two years: given the labour of four convicts for the first nine months and two for fifteen months longer, victualled and clothed at the public expense.

The second class to be victualled and clothed for two years and be allowed the labour of two convicts for the same period. 
TABLE 2

Land Grants

Date

Grantee
Area*

(acres)

\section{Locality}

A. Inifial Land Grants

15 Aug 1804

Fosbrook, Leonard

100

Bowden, Matthew

Johnson, Lieut J.M.

Miller, Edward

18 Der 1805

Issel, Thomas

Hayes, Thomas

Hayes, Henry

Nichols, William

Preston, Thomas Richard

Pitt, Richard

Cockerill, William

Blinkworth, John

Dacres,

Littlefield, Thomas Figget

Peters, Mary

Hayes, Martha

Sladden, Capt. William

Knopwood, Rev. Robert

Lord, Lieut Edward

Faulkner, -

Littlejohn, Robert

Harris, George Prideaux

Fosbrook, Leonard

Mansfield, Michael

Parish, -

Kelly, Samuel

Guest, George

Clark, Richard

Power, Mathew

Hopkins, Thomas

B. Lands granted by Paterson

9 May 1809

12 Sep 1809

Lord, Lieut Edward

Knopwood, Rev. Robert

500

for the time being

100

Bader, John

500
Near Humphrey's Rivulet

do.

do.

do.

At Stainforth's Cove

do.

do.

do

do.

do.

do.

do.

do.

do.

On the Brook, River Derwent On Swamp Lagoon, River Derwent

At Sandy Bay

Cottage Green

Adjoining Cottage Green

Near the Rivulet

At Miller's Bay

At Sandy Bay

At Sullivan Cove

East side of Derwent do.

West side of Derwent

At Sullivan Cove

do.

do.

do.

River Derwent

Clarence Plains

do.

do.

River Derwent

$* 1$ acre $=0.4047$ ha 
The third elass to be victualled and clothed for twelve months and be allowed the labour of two convicts for the same period, and to be in other respects assisted as new settlers.

All classe to be supplied with implements and tools equivalent to those they may have been possessed of and may not have had it in their power to remove.

Stock left behind is to be taken by Government at a fair evaluation and paid for in clothing or other necessaries as the public stores may furnish."

These terms were very generous indeed, but no attempt was made to enable Lieut Governor Collins to carry them out, so that there was great dissatisfaction amongst the settlers and constant complaints against the Government. Some, however, agreed to relieve the Government of their obligation to provide buildings for them if they received stock of equal value. The Lieut Governor was able to satisfy them with a few sheep and Bengal cows. The coming of the Norfolk Islanders led to the opening up of more of the country for farming and led to the colony becoming more selfsupporting in the matter of food supplies. Thankfully a shipment of 252 Bengal cows arrived in March 1809 (having been ordered in March
1807) from India. These were a great help with the influx of these settlers.

\section{LAND GRANTS AND AGRICULTURE}

Collins' commission as Lieut Governor did not empower him to issue land grants, only recommend them. So he issued location orders which entitled the settler to select his land and locate himself upon it. The first schedule of land granted by Governor King is shown in table $2 \mathrm{~A}$.

The next list available is of lands granted by Lieut Governor Paterson and is shown in table $2 \mathrm{~B}$.

It will be noted that there is no list of grants between 1 January 1806 and 9 May 1809. Many must have been made, especially in view of the large number of settlers who arrived from Norfolk Island in 1808. Many settlers did not bother to procure the official grant, the location orders from the Lieut Governor being deemed sufficient title to their land. Collins made it known that he would not allow applications for grants till the settlers had proved their sincerity and industry.

Some idea of the progress made in agricultural development can be gleaned from table 3 , extracted from the few official returns available.

TABLE 3

Agricultural Progress, 1806-09

\begin{tabular}{|c|c|c|c|c|c|c|c|c|c|}
\hline \multirow[t]{2}{*}{ Date } & \multirow[t]{2}{*}{ Wheat } & \multirow[t]{2}{*}{ Barley } & \multirow{2}{*}{$\begin{array}{c}\text { Acres } \\
\text { held }\end{array}$} & \multicolumn{6}{|c|}{ Number } \\
\hline & & & & Horses & Sheep & Buils & Cows & Calves & Oxen \\
\hline$\ldots-\cdots$ & $\cdots \cdots \cdot-\cdots$ & $\ldots \ldots$ & $\ldots$ & $\ldots \ldots$ & $\ldots \ldots$ & $\ldots \ldots$ & $\ldots \ldots$ & $\ldots \ldots \ldots$ & $\cdots \cdots$ \\
\hline \multicolumn{10}{|c|}{ Derwent Settlement } \\
\hline \multicolumn{10}{|l|}{ Oct 1806} \\
\hline Crown & 39 & - & - & 6 & 282 & 70 & 126 & - & 5 \\
\hline Settlers & 64 & 29 & 2290 & - & 436 & 3 & 64 & - & 11 \\
\hline \multicolumn{10}{|l|}{ Jul 1807} \\
\hline Crown & 23 & 13 & - & 6 & 301 & 7 & 26 & 115 & 5 \\
\hline Settlers & 77 & 50 & 2704 & - & 747 & - & 72 & 62 & 3 \\
\hline \multicolumn{10}{|l|}{ May 1809} \\
\hline Crown & 17 & - & - & 6 & 122 & 2 & 224 & 96 & -- \\
\hline Settlers & 181 & 56 & 2979 & 4 & 969 & 4 & 98 & 23 & 42 \\
\hline \multicolumn{10}{|c|}{ Port Dalrymple } \\
\hline \multicolumn{10}{|l|}{ Apr 1807} \\
\hline Crown & & & & 2 & 154 & 3 & 229 & 137 & 1 \\
\hline Settlers & & & & 6 & 151 & 2 & 14 & 10 & - \\
\hline
\end{tabular}


The return dated May 1809 apparently does not include the Norfolk Island settlers, only those located at New Town being given. Their land would make a considerable increase in the total acreage held, and their labour and stock would swell to a small extent the totals of acres cultivated and stock held.

The colony was beginning to move ahead. There was a steady increase in cultivation, but the methods of agriculture were still crude and unprofitable. Grain was mostly chipped in, leading to poor crops. Continued cropping of the same ground exhausted the soil and resulted in even poorer yields. It is said that some "farmers" were so indolent as to depend upon self-grown grain for a crop. Very few of the early settlers who located themselves at New Town were originally farmers, and lack of knowledge, implements and labourers all combined to prevent them making the best use of their situations. Their gardens contributed largely to their subsistence. Vegetables grew in abundance, especially potatoes, beans and peas. The potatoes were much in demand and the settlers turned large quantities into the Commissariat Store in exchange for articles which they required. Their stock was also on the increase, but here again the bulk of the cows were in the Government herds. Until cattle numbers increased considerably, and were distributed better amongst the settlers, the colony could not hope to be nearly self-supporting in meat.

Sheep do not show the increase from 1806 to 1809 that we would expect. Probably many of them had been slaughtered for food during the time the colony was in want. But a return made on $21 \mathrm{March}$ 1811 , gives the number of sheep belonging to "settlers etc" as 1935 and for Port Dalrymple 1638. These are remarkable increases. They proved the suitability of the Tasmanian climate for sheep and gave promise that woolgrowing would become one of the staple industries of the country.

The sheep were of the Teeswater breed (fig. 1), with a slight admixture of the Leicester brecd and a few imported from Bengal. But they were very badly managed. It was the custom to run sheep of all ages and sizes together in the same flock, and lambs were allowed to breed before they attained the age of seven months. The wool was of poor quality and not worth anything. It was allowed to rot in heaps on the farms, or was burnt to get rid of it. Sometimes the sheep were not shorn at all. The faet is that the settlers were intent not on producing wool, which was then unsaleable, but meat which they could sell to the Commissariat Store. Under such conditions little improvement in woolgrowing
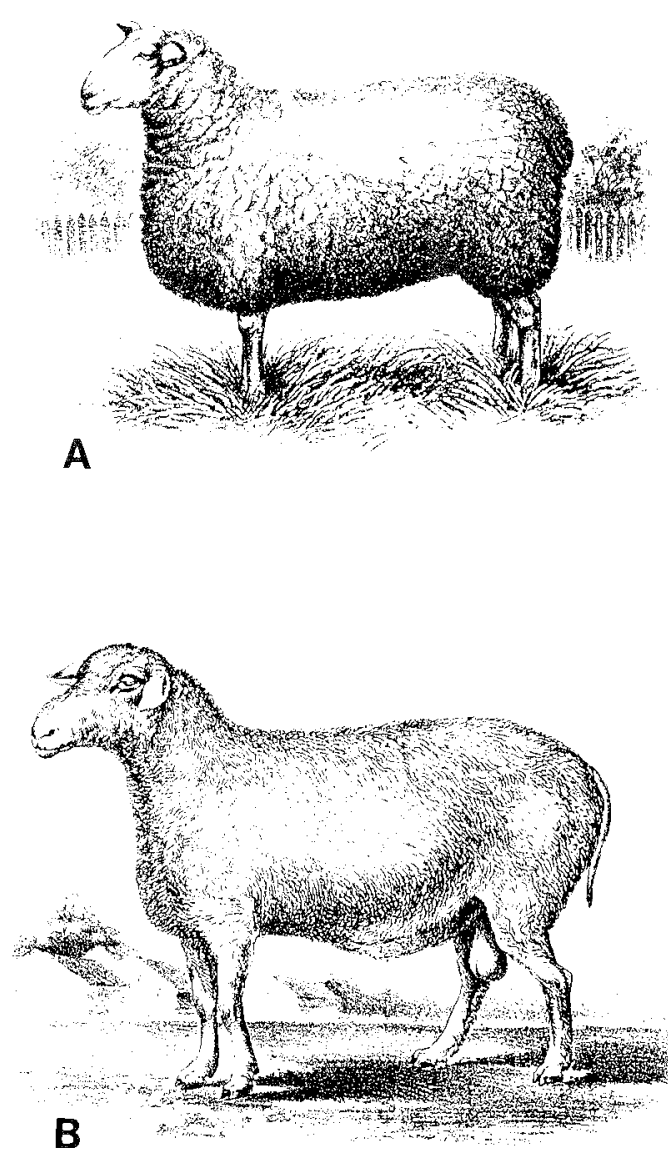

FIG. I-Two of the original sheep breeds brought to Tasmania. The Leicester (A) is still to be found in small numbers in Tasmania. Its importance was in the formation of Tasmania's main sheep breed, the Polwarth. The Teeswater (B) is an old English breed not now found in Tasmania.

could be looked for. Later Governor King gave Lieut Lord a ram as near the Spanish breed as Government possessed and also sent two for the use of the Government flock "as the amelioration of the wool throughout these colonies is an object much recommended by His Majesty's Government; if it is found your sheep thrive and their wool 
improves from the rams now sent, it will be desirable you should be furnished with rams nearer the true Spanish breed". It was not until 1820 that Governor Macquarie procured some of MacArthur's best merino rams and sent them to the Derwent to improve the quality of the flocks there.

\section{CONCLUSION}

What then were the factors which severely limited growth and development during the period 1803-10? (In fact this situation continued until the early 1820 's when Governor Arthur took charge of the colony.)

The limiting factors were:

(a) lack of agricultural expertise,

(b) non-availability of horses and oxen for tilling land,

(c) poor productivity due to poor agricultural methods,

(d) severity of climate,

(e) supply shortages,

(f) abandoning farming in favour of kangaroo hunting which was much easier,

(g) incompetence at all levels,

(h) bribery, corruption, theft, dishonesty, fecklessness -

"... continually inept and rascally pubic servants and private citizens strove to make money from the government by short changing it and blatantly robbing it blind" ... "If the safety of Van Diemen's Land, like Sodom and Gomorrah, had depended on finding ten honest men it would have been swallowed up in all its iniquity"! (Robson 1983)

(i) aggression of the aborigines, (j) gruos and smut affecting crops,

(k) drunkenness,

(I) sourness" of the ground,

(m) drought,

(n) labour troubles,

(o) poor quality of tools,

(p) bushrangers, and

(q) sickness - scurvy, diarrhoea and catarm.

The result was that the new colony was dependent for some time.

\section{ACKNOWLEDGEMENTS}

This study was undertaken in 1985 whilst at the Australian Bureau of Statistics, Hobart, on interchange from the Department of Agriculture, Hobart. My thanks go to both the Department of Agriculture and the Australian Bureau of Statistics for their support of this interchange.

\section{REFERENCES}

BARRETT, W.R., 1936: HISTORY OF TASMANIA TO THE DEATH OF LIEUTENANT-GOVERNOR COLLINS IN 1810. W.R. Barrett, Hobart.

HRA: HISTORICAL RECORDS OF AUSTRALIA. Principally Series III, Vol.1 (1803-12). The Library Committee of the Commonwealth Parliament.

NICHOLLS, M. (Ed.), 1977: THE DIARY OF THE REVEREND ROBERT KNOPWOOD 1803I838, FIRST CHAPLAIN OF VAN DIEMEN'S $L A N D$. Tasmanian Historical Research Association, Hobart.

ROBSON, L., 1983: A HISTORY OF TASMANIA. Oxford University Press.

(accepted 4 November 1987) 